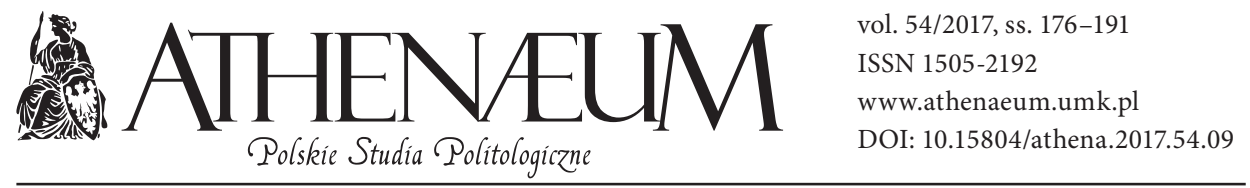

\title{
EUROPA ŚRODKOWO-WSCHODNIA W POLSKIEJ POLITYCE ZAGRANICZNEJ. OD HISTORYCZNYCH ODNIESIEŃ PO WSPÓŁCZESNE WYZWANIA
}

\author{
CENTRAL AND EASTERN EUROPE IN THE POLISH \\ FOREIGN POLICY: FROM HISTORICAL REFERENCES \\ TO CONTEMPORARY CHALLENGES
}

Artur Niedźwiecki*

\begin{abstract}
ABSTRAKT
Prowadzenie skutecznej polityki, nieulegającej ideologicznym manifestacjom, może opierać się na unijnym instrumentarium nawet pomimo aktualnego kryzysu integracji europejskiej. Rozsądną odpowiedzią na dylematy geopolityczne Rzeczpospolitej nie wydaje się tzw. „idea jagiellońska", gdyż potencjalnie stanowi ona przeciwieństwo istniejących filarów bezpieczeństwa narodowego, tj. NATO i UE. Redukowanie polskiej polityki do anachronicznych fantazji o wspólnocie środkowoeuropejskiej może powodować obniżenie znaczenie Polski w strukturach euroatlantyckich. Członkostwo $\mathrm{w}$ instytucjach świata zachodniego, polegające m.in. na współpracy z Niemcami, stanowiło do tej pory o bezpieczeństwie Rzeczpospolitej, choć obecnie nie przystaje ono do historycznej koncepcji tzw. „polityki piastowskiej”, głównie
\end{abstract}

Conducting an effective policy, without ideological manifestations, can be based on the EU instruments, regardless of the crisis of the European integration. Reasonable answer to the Polish geopolitical dilemmas is not the so-called "Jagiellonian idea", which can be perceived as opposition to existing pillars of national security, i.e., NATO and the EU. Reduction of the Polish policy to anachronistic fantasies about Central European community may diminish the importance of Poland in the Euro-Atlantic structures. Membership in the institutions of the Western world, relying inter alia on the cooperation with Germany, has served so far as a guarantee of the Polish security, however currently it does not suit entirely to the historical concept of the so-called "Piast policy", mainly due to the notice-

* Uniwersytet Łódzki, Wydział Studiów Międzynarodowych i Politologicznych. 
$\mathrm{z}$ uwagi na obserwowany proces dezintegracji wspólnoty europejskiej.

Słowa kluczowe: polityka jagiellońska, Europa Środkowo-Wschodnia, wspólnota europejska able process of disintegration of the European community.

Keywords: Jagiellonian policy, Central and Eastern Europe, European community

\section{WPROWADZENIE}

Jeśli „państwo polskie istnieje tylko teoretycznie”, jak uważa były minister spraw wewnętrznych Bartłomiej Sienkiewicz ${ }^{1}$, powinniśmy ocenić - zupełnie na poważnie - możliwości odtworzenia „centrum grawitacyjnego” w naszym regionie, co przez niektórych określane jest, trochę pompatycznie, mianem reaktywacji „polityki jagiellońskiej”. Nie brakuje badaczy, którzy pragnęliby czerpać pełnymi garściami z chwalebnej, choć nieco zakurzonej, tradycji I Rzeczypospolitej i którzy utyskują, że duch prawdziwego republikanizmu - wynikający przykładowo z Konstytucji 3 maja - jest obecnie taki niedoceniany (Cichocki, 2010). Jednakże chaos okresu państwa polsko-litewskiego nie był li tylko wytworem pruskiej propagandy! Niestety w publicystyce europejskiej XVIII wieku Rzeczpospolita Obojga Narodów ${ }^{2}$ odgrywała rolę wymownej ilustracji wszechobecnej anarchii i zacofania, co kontrastowało z obrazem ładu i porządku panującego w państwach ościennych. W istocie nasze szacowne dziedzictwo, przynajmniej wedle niektórych znawców problematyki, mogło skutkować infantylizacją oraz kulturowym upośledzeniem Polaków, niezdolnych do podjęcia rywalizacji z innymi narodami Europy. Rodzima tradycja spowodowała bowiem odizolowanie naszego państwa od procesów modernizacji i, w rezultacie, anachroniczna Polska zaprzepaściła szansę na zainicjowanie trwałej federacji w sercu kontynentu. Można by przecież zadać pytanie, dlaczego wybitna spuścizna państwa Jagiellonów nie zagwarantowała nam eksponowanego miejsca w debacie na temat przyszłości Europy? W końcu jako naród, który stworzył jedną z pierwszych konstytucji, z innowacyjnym jak na owe czasy konceptem wielokulturowego obywatelstwa, Polacy byli predestynowani do przewodzenia debacie na temat konstytucjonalizacji wspólnoty. Zamiast tego pamięć o znamiennym polskim wkładzie w jednocze-

\footnotetext{
${ }^{1}$ Bartłomiej Sienkiewicz - minister spraw wewnętrznych Polski w latach 2013-2014.

2 Korona Królestwa Polskiego i Wielkie Księstwo Litewskie istniało w latach 1569-1795 na mocy Unii Lubelskiej.
} 
nie Europy wyparta została przez oficjalną narrację o francusko-niemieckim pojednaniu jako fundamencie współczesnej Unii.

Celem niniejszego artykułu jest zaprezentowanie problematyki polityki zagranicznej Rzeczpospolitej względem regionu Europy Środkowo-Wschodniej, począwszy od jej inspiracji historycznych aż po kwestię aktualnych zagadnień geopolitycznych, głównie za pomocą takich narzędzi badawczych, jak: metoda historyczna, ujęcie systemowo-komparatystyczne, a także analiza czynnikowa (Chodubski, 2006). W polu badawczym pracy znajdują się zarówno współczesne relacje Polski z państwami środkowoeuropejskimi, będącymi aktualnie członkami unijnych struktur, jak również stosunki Warszawy ze wschodnimi sąsiadami Unii Europejskiej, nieuczestniczącymi w procesie zjednoczeniowym na starym kontynencie. Dopełnieniem w/w zakresu badań jest refleksja nad polską aktywnością w regionie na tle obecnej sytuacji politycznej w Europie, zwłaszcza w związku z ewolucją niemieckiej strategii europejskiej oraz procesami dezintegracyjnymi, wywołanymi tzw. „Brexitem”3. Główną hipotezę badawczą, której weryfikacja jest zasadniczym zadaniem przedmiotowego tekstu, stanowi stwierdzenie, iż aktualna polityka Polski względem omawianego regionu nie mieści się w żadnej z dwóch wielkich koncepcji historycznych, znanych pod pojęciami „polityki jagiellońskiej” oraz „polityki piastowskiej”, lecz jest emanacją zupełnie nowego podejścia do bieżących wyzwań, które wynika z coraz bardziej dojmującego kryzysu, a także braku strategicznych pewników, z jakim mamy do czynienia od dłuższego czasu w Europie. Zasadniczym punktem odniesienia dla oceny polityki Rzeczpospolitej wobec Europy Środkowo-Wschodniej pozostaje bogata literatura przedmiotu, zarówno w postaci licznych pozycji naukowych, jak i tekstów publicystycznych, stanowiąca analizę m.in. szeroko pojętej koncepcji paryskiej „Kultury”, uznawanej za jedną z najistotniejszych propozycji doktrynalnych dla działań zewnętrznych Warszawy, ale również i refleksja na temat innych, równie wpływowych poglądów o roli i znaczeniu Polski w regionie, będącym przedmiotem niniejszego artykułu.

\section{U ŹRÓDEt POLSKIEJ MYŚLI MOCARSTWOWEJ}

Spoglądając w przeszłość, nie można oprzeć się wrażaniu, że sąsiedztwo wrogich mocarstw stanowiło niezwykle twardą lekcję, która wywarła przemożny wpływ

${ }^{3}$ W referendum przeprowadzonym w dniu 23 czerwca 2016 r. 51,9 \% obywateli brytyjskich biorących udział w głosowaniu opowiedziało się za wystąpieniem Wielkiej Brytanii z Unii Europejskiej. 
na naszą tożsamość. Można nawet pokusić się o stwierdzenie, że polskość ukształtowała się w radykalnej opozycji do idei imperium (Nowak, 2004). Bo to swoiście rozumiane poczucie wolności oraz pęd ku zachowaniu swobód obywatelskich motywowały Polaków do opierania się tyranii i autokracji. Nasi rodacy od zawsze wykazywali szczególną wrażliwość na wszelkie przejawy nadużycia władzy oraz kontestowali silne rządy, uzurpujące sobie prawo do ingerencji w sferę osobistych uprawnień jednostek. Paradoksalnie, powyższe koegzystowało z irracjonalnymi snami o potędze, promieniującej na cały region Europy Środkowo-Wschodniej (dalej: EŚW). Nie ulega jednak wątpliwości, że status lidera tej części kontynentu wymagał akumulacji potencjału, a tymczasem nasi rodacy woleli hołdować podejściu: „Polska nierządem stoi”. W istocie odwieczna niechęć do sztywnych rygorów organizacyjnych, jak również zhierarchizowanych struktur wykonawczych nie sprzyjała budowie operatywnego państwa, zdolnego do przewodzenia związkowi podmiotów EŚW. A bez poparcia działań dyplomatycznych realnymi zasobami „projekt jagielloński” pozostawał fantazją państwa, działającego ledwie „jak gdyby było mocarstwem”. Jednakże - według ojców założycieli II Rzeczypospolitej - w naszej sytuacji geopolitycznej niepodległość należało połączyć z ideą wielkości, a zatem Polska winna była odznaczać się wielkością, gdyż słabowity podmiot nie mógł przetrwać samodzielnie między potęgami

Nic zatem dziwnego, iż do kanonu polskiej raison d’etat weszło wspieranie państw powstałych na ruinach imperiów i, w rezultacie, odsuwanie od naszych granic potężnych sąsiadów. Jedyną słuszną strategią miało być utrzymywanie antagonizmów pomiędzy mocarstwami możliwie jak najdłużej, by uchronić region przed ich agresywnymi zapędami, a zarazem rozmontować zdolności przeciwnika poprzez tendencje odśrodkowe. Wymownym przykładem tej „relatywnej” pozycji Polski stało się postrzeganie jej roli jako funkcji stosunków niemiecko-rosyjskich, a więc wygaszenie rywalizacji między potęgami rodziło realne ryzyko ich sojuszu wymierzonego w interesy Rzeczpospolitej (Ujazdowski, 2008). Oczywiście nawet najsprytniejsze działania nie mogły doprowadzić do zmiany tego jakże niepewnego polskiego położenia na mapie politycznej Europy. Bezpieczeństwo EŚW miało jednak ulec istotnemu wzmocnieniu w wyniku podziału dużych graczy na szereg organizmów państwowych, o znacznie uboższym potencjalne polityczno-militarnym. Zatem integracja mniejszych podmiotów niweczyła plany sąsiednich imperiów, które traktowały tę część kontynentu

${ }^{4} \mathrm{~W}$ okresie dwudziestolecia międzywojennego tzw. „myśl mocarstwowa” prezentowana była m.in. na łamach pisma „Bunt Młodych” przez Jerzego Giedroycia i Adolfa Bocheńskiego. 
niczym obszar swej naturalnej ekspansji. Zgodnie bowiem z powszechną opinią, imperia potrzebują peryferii do narzucania własnego porządku, a upodmiotowienie ich obrzeży prowadzi do nieuchronnej dezintegracji centrum poprzez restaurację niepodległości mniejszych krajów.

Wedle polskich patriotów istniały tak naprawdę dwie - konkurencyjne metody zachowania niepodległości, tj.: 1) wzmocnienie wewnętrznego potencjału albo 2) utworzenie silnego związku państw ościennych. Dla rodzimej „myśli mocarstwowej” szczególnie ta druga opcja była symptomatyczna (Rojek, 2012), gdyż zakładała zbudowanie wielonarodowej federacji obejmującej terytorium Ukrainy, Litwy i Białorusi (antyrosyjska „doktryna ULB”) i/lub Czech, Słowacji i Węgier (antyniemiecka „doktryna ABC”). Zwolennicy „podejścia jagiellońskiego" twierdzili bowiem, iż Rzeczpospolita winna zabiegać o powołanie rodzaju środkowoeuropejskiego związku, jeżeli brakuje jej wystarczających zasobów do obrony własnej podmiotowości. Gdyby bowiem Polska dysponowała siłą dorównującą Niemcom lub Rosji, nie trzeba by podejmować mozołu integracji z sąsiadami. Nawiasem mówiąc, akolici „idei mocarstwowej” przekonywali, że Warszawa musiałaby poprzestać na sojuszu z imperiami, gdyby nasi rodacy zaniechali wysiłku tworzenia związku politycznego w regionie, lecz wówczas osamotniona Rzeczpospolita skończyłaby - w najlepszym razie - jako ich kondominium.

Praktykowanie nieograniczonej suwerenności przez państwa EŚW przesądzało - w ocenie luminarzy idei federacyjnej - o ich słabowitości, gdyż kraje te nie mogły w pojedynkę i w nieskończoność opierać się presji ekspansywnych sąsiadów. Zatem zdaniem wyznawców „polityki jagiellońskiej”, jeśli region pragnął utrzymać autonomię, jego państwa winny były przekazać część swej suwerenności na rzecz szerszej wspólnoty, by ocalić egzystencję w obliczu agresywnych graczy. To dlatego mali i średni aktorzy EŚW mieli utworzyć rodzaj sojuszu, gdyż tylko wielopoziomowa integracja Europy mogła stanowić gwarancję utrzymania równowagi między potęgami (Bocheński, 1927). Dla Polaków efemeryczności Ligi Narodów, składającej się z formalnie równych podmiotów, była bowiem wymownym antyprzykładem, którego należało unikać przy tworzeniu międzynarodowego aliansu, ponieważ zasada formalnej równości członków zapewniała korzyści przede wszystkim mocarstwom. Nasi federaliści widzieli zatem zjednoczoną Europę jako asocjację regionalnych związków, odrzucając tym samym koncepcję stowarzyszenia narodów, postulowaną przykładowo przez niemieckich badaczy. Pomimo formalnej równości największe państwa zawsze 
byłyby bowiem w stanie zdominować całą organizację. W tym miejscu należy wskazać, że część rodzimych patriotów popierała koncepcję przystąpienia do Unii Europejskiej w 2004 roku nie w pojedynkę, lecz wspólnie jako koalicja całego regionu, gdyż jedynie wówczas szersza wspólnota gwarantowałaby wymierne korzyści i sprawiedliwość wszystkim jej członkom. W przeciwnym wypadku mali i średni gracze mieli niechybnie zostać zredukowani do roli satelitów, co prawdopodobnie stanowiło historyczne podglebie dla obaw i lęków żywionych przez dzisiejszych eurosceptyków (Szczerski, 2008).

Należy zauważyć, że gdy Rosja stała się geopolityczną potęgą, uzyskała ona potencjał niezbędny do ugruntowania swej dominacji w Euroazji. W tym momencie Moskwa uzyskała przemożny wpływ na Europę Środkowo-Wschodnią, a Rzeczpospolita przestała cieszyć się suwerennością (Bączkowski, 1938). Prawdziwym skandalem była ówczesna kruchość struktur państwowych oraz brak potencjału do obrony granic, zwłaszcza że Polska niespecjalnie mogła polegać na gwarancjach Zachodu. W takiej sytuacji Warszawa zmuszona została - de facto - do rezygnacji z własnych ambicji geopolitycznych, które zakładały nadawanie tonu współpracy regionalnej. Przez dziesięciolecia Rzeczpospolita funkcjonowała zatem jako ledwie konsument ładu dyplomatycznego, zaprowadzonego przez ościenne mocarstwa. W rezultacie nie mogła ona prowadzić własnej polityki, a Polacy musieli nauczyć się żyć w granicach etnograficznych, jako pozbawiony sprawczości naród o średniej wielkości.

Rosyjskie Imperium postrzegane było przez naszych rodaków - przeważnie - jako „więzienie narodów” oraz „żandarm Europy”. Kreml wolał bowiem otaczać się wasalami, takimi jak PRL lub Czechosłowacja, aniżeli posiadać przyjaznych sąsiadów, którzy z własnej woli dążyliby do współpracy (Nowak, 2010). Z rosyjskiego punktu widzenia - dla zachowania hegemonii w EŚW - niezbędne stało się zatem sprowadzenie Rzeczpospolitej do podrzędnej roli klienta. W optyce Moskwy, Warszawa musiała być tylko satelitą, ponieważ jej niezależność wadziłaby interesom geopolitycznym Kremla. Gdyby aspiracje Polski zostały spełnione, oznaczałoby to niechybne rozmontowanie systemu rosyjskiej dominacji w regionie. Innymi słowy, w ocenie zwolenników „myśli mocarstwowej” Warszawa nie mogła zaznać spokoju, dopóki Moskwa utrzymywała status imperialny w EŚW. Z uwagi na powyższe, Rzeczpospolita winna była stworzyć sprawne państwo narodowe, by już nigdy nie odgrywać roli „Chrystusa Narodów”, lub też ofiarować istotny wkład w budowę paneuropejskiej federacji, mającej na celu oddalenie widma konfliktu zbrojnego na starym kontynencie (Najder, 2010). 


\section{POLITYKA JAGIELLOŃSKA W PRAKTYCE}

Wypada zadać pytanie, czy nasi sąsiedzi rzeczywiście zainteresowani są polskim przywództwem w regionie? Przecież państwa te cieszą się obecnie niepodległością oraz względnym poziomem zamożności, więc - być może - doktryna federalizacji straciła już swoje raison dêtre. Trzeba przyznać, że dziś wspólnota interesów w Grupie Wyszehradzkiej - pomimo kilku incydentalnych wydarzeń praktycznie nie istnieje, głównie z uwagi na odmienną percepcję problemów międzynarodowych. Nawet wspólne wyzwania imigracyjne, jak również zagrożenia geopolityczne, nie przekonują liderów EŚW do solidarnego działania. Duch dobrej kooperacji aktualnie jawi się jako fantasmagoria, ponieważ ostatnimi laty państwa regionu wolały realizować indywidualne strategie aniżeli tworzyć zespołowe inicjatywy. W tym miejscu warto wskazać, iż urzeczywistnienie „ambicji jagiellońskich" mogłoby tak naprawdę pogłębić podziały w łonie Unii. Nie ulega bowiem wątpliwości, że przez ostatnią dekadę Polska walczyła z fenomenem „zmiennej geometrii”, a „federacja środkowoeuropejska” oznaczałaby utworzenie odrębnego kręgu integracji, stanowiącego alternatywę dla projektu zachodnioeuropejskiego. Pomijając brak faktycznego potencjału tkwiącego w tym scenariuszu, jego ziszczenie się mogłoby oznaczać realne przyspieszenie rozkładu ogólnoeuropejskiej jedności - już i tak wydatnie nadwątlonej przez tzw. „Brexit” - i to spowodowane przez państwo, które jest obecnie jej największym beneficjentem. W rzeczy samej dla szermierzy polskiej racji stanu silna „Grupa Jagiellońska” stanowi poręczną alternatywę dla zdominowanej przez francusko-niemiecko-włoski triumwirat Unii. Jednak musimy pamiętać, że w przeszłości niekontrolowana aktywność Rzeczpospolitej „we wszystkich kierunkach” zbyt często kończyła się samotną i bezowocną „fanfaronadą”, przypominającą „prymitywną hegemonię”, której jedynym rezultatem było zniechęcenie sąsiadów do współpracy, zamiast proponowania konstruktywnych rozwiązań dla całej wspólnoty.

Powstaje dylemat, czy perspektywę budowy silnego związku EŚW winna poprzedzać jakaś forma porozumienia Warszawy z coraz silniejszym w unijnych kręgach Berlinem (Konopacki, 2010)? ${ }^{5}$ Wedle kanclerza Bismarcka polska polityka zawsze była romantyczna (w odróżnieniu od politycznej literatury), bo jedynie poeci mogli twierdzić, że Rzeczpospolita samodzielnie zainicjuje

5 Zdaniem Stanisława Konopackiego słowa Juliusza Mieroszewskiego: „nowy układ Europy może być zbudowany tylko z Niemcami” w dzisiejszej, dotkniętej kryzysem Europie stają się niezwykle aktualne. 
federację w regionie, przy zachowaniu chłodnej obojętności Niemiec. Jednak pamiętamy, że polityka nie może być ani romantyczna, ani naiwna, gdyż w przeciwnym wypadku jej koszty bywają druzgocące. Tymczasem nasi rodacy nadal są pogrążeni w zamierzchłej przeszłości, uniemożliwiającej przekroczenie barier i odrzucenie geopolitycznego fatalizmu, a także tradycyjnych pretensji skierowanych do reszty Europy. Oskarżenia adresowane do partnerów europejskich, zarzucające im brak lojalnej współpracy, niestety wciąż stanowią polskie spécialité de la maison. Zatem niepoddawanie się narracjom tłumaczącym wszystkie nasze porażki złą wolą Zachodu wydaje się mieć pierwszorzędne znaczenie. Niemcy (a tym bardziej Francja) nigdy nie miały moralnego obowiązku wspierania polskich postulatów geopolitycznych. Nawiasem mówiąc, idea ścisłego związku państw środkowoeuropejskich powraca regularnie w naszych debatach, gdy pojawia się wrażenie wzrostu znaczenia rządów „, dyrektoriatu europejskiego”. Powyższe jest szczególnie widoczne teraz, gdy widmo wyjścia Wielkiej Brytanii z Unii prowadzić może do reaktywacji koncepcji tzw. „Europy karolińskiej”, wieszczącej nieuchronne wykluczenie postkomunistycznych „newcomers" z twardego jądra integracji. Niestety coraz bardziej donośne stają się głosy, iż w EŚW brakuje zdolności, by koordynować wspólne projekty o znaczeniu wykraczającym poza własny region. A przecież gdyby Polska była sterowna, mogłaby w pojedynkę położyć podwaliny pod przyszłą wspólnotę środkowoeuropejską.

Z pewnością długie lata zajmie przezwyciężenie znaczących różnic między państwami EŚW, a na realizację konkretnych rozwiązań instytucjonalnych przyjdzie nam jeszcze długo poczekać. Tymczasem, możemy radować się, iż Rzeczpospolita zdołała wydostać się z „historycznej pułapki”, polegającej na braku suwerenności sąsiadów, gdyż bez ich niepodleglości, polska niezawisłość nie byłaby do utrzymania przez okres dłuższy niż dwadzieścia lat. W razie urzeczywistnienia projektu środkowoeuropejskiego należałoby jednak porzucić wybujałe ambicje nieograniczonej dominacji, a zarazem przyjąć rolę wiarygodnego partnera działającego jako primus inter pares. Zdaniem rzeczników „opcji jagiellońskiej" potencjalna koalicja EŚW mogłaby stać się rozgrywającym na kontynencie, stanowiąc przeciwwagę dla rosnących wpływów najbogatszych członków Unii. Jak przekonują bowiem luminarze racji stanu, budowanie pozycji Rzeczpospolitej na bazie Trójkąta Weimarskiego jest utopią, gdyż zauważalna asymetria potencjałów uczyni z niej jedynie młodszego partnera Francji czy Niemiec (Kędzierski, 2014).

Biorąc pod uwagę powyższe, za co najmniej wątpliwe należy uznać niemieckie podejście do polskiej aktywności w EŚW. Głębsza integracja Grupy Wyszehradz- 
kiej z całą pewnością wymagałaby znaczącego zaangażowania Berlina. Natomiast w ocenie niektórych piewców tzw. ,idei mocarstwowej” Niemcy nigdy nie były specjalne zainteresowane polskim przywództwem w regionie, gdyż pragnęły samodzielnie określać tam reguły gry. Po roku 1989 omawiana część kontynentu - przynajmniej w sensie ekonomicznym - została skutecznie zdominowana przez Berlin, który pełnił rolę jej promotora (a nie Warszawa!) i czynił to bez zbędnej „megalomanii” (Szatkowski, 2015). Dziś w Polsce dyskutujemy nad mirażem wspólnoty środkowoeuropejskiej, lecz nasz zachodni sąsiad konsekwentnie milczy o „niemieckiej Europie”, która staje się coraz bardziej ewidentna. Przyklejanie nierozumnych etykietek - w istocie - może uchodzić za specjalność Polaków, natomiast Niemcy wolą systematycznie realizować własne pomysły, pełniąc rolę „hegemona mimo woli”, który proponuje „ratowanie wspólnoty” zamiast budowy nowego imperium.

Tak długo jak Rzeczpospolita nie będzie dysponować poważną ofertą dla sąsiadów, a nic nie wskazuje, aby powyższe uległo zmianie, Warszawa nie odnotuje większych sukcesów w polityce środkowoeuropejskiej. Zdolność do nawigowania w regionie wymaga bowiem posiadania zasobów ekonomicznych, które obecnie posiadamy w raczej symbolicznym zakresie. Polska jest uzależniona od Berlina w takim samym stopniu, jak inne państwa EŚW, a zatem idea projektu pozostającego w opozycji do Niemiec przeczy cnocie roztropności (Sikorski, 2011). W istocie groteskowy plan przebudowy regionu pod polskie dyktando charakteryzuje się surrealizmem, a zarazem stanowi rodzaj niebezpiecznej utopii, która odwraca naszą uwagę od prawdziwych problemów (Lazari de, 2006). Można zadać pytanie, w jaki sposób Polska ma realizować śmiałą strategię emancypacji EŚW, jeśli sama stoi na rozdrożach w zakresie polityki europejskiej? Przekonującą odpowiedzią na powyższe jest próba zainicjowania - wreszcie w sposób profesjonalny - takiej formy aktywności, która wykorzystałaby zamiast samotnych eskapad - instrumentarium unijne, będące - mimo objawów przejściowej zadyszki - wciąż niebagatelnym rezerwuarem skutecznych środków politycznych.

Region środkowoeuropejski - od zawsze strategicznie ulokowany - był obiektem ekspansji z różnych stron, co nierzadko skutkowało jego podporządkowaniem ościennym hegemonom, którzy nie sprzyjali dążeniom do jego dobrowolnej unifikacji (Bartosiak, 2014). Autentycznie niezależna EŚW byłaby bowiem niekontrolowanym graczem, zdolnym do opierania się zewnętrznym wpływowym. Dziś Polska nie dysponuje zaufaniem partnerów, niezbędnym do zainicjowania pogłębionej współpracy w regionie. Przykładowo, Litwa - z uwagi 
na burzliwą przeszłość - wyraża daleko idący sceptycyzm względem „idei jagiellońskiej", której symbolika w Wilnie wywołuje co najmniej irytację. Jeśli natomiast rozważamy „wektor białoruski”, to musimy przyjąć do wiadomości, że Mińsk nie spełni skrajnie nierealistycznych oczekiwań co do wewnętrznej demokratyzacji. W przeszłości - głównie z uwagi na retorykę prezydenta RP L. Kaczyńskiego - Polacy żyli złudzeniami na temat ich rzekomo kluczowej roli w EŚW, natomiast obecnie - niestety - trzeba dostosowywać wybujałe ambicje do nieubłaganych realiów geopolitycznych, aniżeli uparcie obstawać przy irracjonalnych „marzeniach o potędze”.

Zgodnie z koncepcją pracy organicznej Rzeczpospolita może wpierw udoskonalić gospodarkę, infrastrukturę oraz armię, a gdy jej zdolności będą przewyższać zasoby krajów ościennych, wspólne projekty pod przewodnictwem Warszawy staną się wykonalne. Tymczasem warto używać instytucji międzynarodowych do powolnej, aczkolwiek systematycznej integracji EŚW, której nie powinien osłabiać obserwowany obecnie kryzys wspólnoty europejskiej. Z kolei zwolennicy „idei federacyjnej” proponują usypianie czujności mocarstw poprzez schlebianie ich próżności i - równocześnie - mozolne budowanie własnego nurtu politycznego w Europie (Kuź, 2014). W ich ocenie Polska winna szukać poparcia pośród mniejszych aktorów regionu, by uniknąć konieczności bliskiej współpracy z potęgami. W towarzystwie mocarstw Rzeczpospolita byłaby bowiem izolowana i w rezultacie nie miałaby innego wyjścia, jak tylko wypełniać rolę ich klienta. Należy zauważyć, iż do wyborów 2015 r. polska dyplomacja dystansowała się od „podejścia jagiellońskiego”, rozumianego jako ambicja do odgrywania większej roli na obszarze byłego ZSRR. Zamiast tego Warszawa raczej hołdowała „polityce piastowskiej”, która stawiała na udział w procesie eurointegracji, a zarazem porzucała bezpośrednie zaangażowanie w tzw. Russkij Mir, jako źródło potencjalnych problemów geopolitycznych, również z uwagi na nadzieje, jakie żywiono względem osławionego „resetu” w relacjach z Federacją Rosyjską. Próba jednoczenia sąsiadów pod sztandarem wrogości do Rosji była bowiem postrzegana jako kardynalny błąd polityczny, a zatem bardziej skupiano się na pogłębianiu integracji, by przyciągać ich pozytywnym przykładem dobrej kooperacji, aniżeli zgubną polityką ostrego sporu i nierozumnej konfrontacji (Kowal, 2009). Katastrofa prezydenckiego Tupolewa w 2010 r. obnażyła bowiem miałkość polskich struktur państwowych i upokorzyła „ideę jagiellońską”, czego skutkiem stało się ówczesne porzucenie snów o aktywnej polityce regionalnej.

Uparte obstawanie ekipy rządzącej Polską po wyborach 2015 r. przy pomyśle utworzenia rodzaju „sojuszu antyrosyjskiego” - być może zasadne emocjonalnie, 
szczególnie w dobie aktualnych zawirowań na Ukrainie - wydaje się jednakowoż dalece nieefektywne. Zróżnicowane reakcje unijnych partnerów na agresywną postawę putinowskiej Rosji po raz kolejny udowodniły nam, że w Europie nie ma miejsca na stałe koalicje i sentymentalną politykę. To dlatego rozsądną receptą na wyzwania w relacjach z EŚW pozostaje przyzwoita "gra na wielu fortepianach", czyli używanie rozmaitych mechanizmów, bez jakichkolwiek historycznych resentymentów, kierując się pragmatyzmem, elastycznością i trzeźwą oceną długofalowych interesów. W tym miejscu należy zauważyć, iż partnerstwo z Niemcami w żadnym razie nie musi oznaczać klientelizmu, a pozycja regionalnego lidera nie powinna być celem samym w sobie, lecz uwieńczeniem całokształtu wieloletnich starań. Bo tylko wtedy Rzeczpospolita będzie postrzegana w EŚW jako kraj, którego opinie są warte wysłuchania, a postawa godna naśladowania. Dziś kondycja Polski jest jeszcze nazbyt chwiejna, gdyż brakuje jej polityczno-gospodarczego potencjału oraz tak potrzebnej świadomości podmiotowości. Natomiast najbardziej znaczący gracze dysponują powyższymi zasobami w stopniu, który pozwala na prowadzenie aktywnych działań zewnętrznych i wywieranie realnego wpływu na wydarzenia. Przecież nie kto inny jak były szef MSZ R. Sikorski stwierdził, że Polska nie będzie tolerowała powtórki „scenariusza gruzińskiego" na Ukrainie, który - nota bene - jest właśnie realizowany, a Warszawa nie posiada możliwości powstrzymania jego głównego reżysera, tj. rosyjskiego prezydenta W. Putina.

Ingerencja Rzeczpospolitej w konflikt w Donbasie mogłaby potencjalnie sprowokować wrogą reakcję Kremla, który postrzega działania Warszawy jako wtrącanie się w wewnętrzne spawy „rosyjskiego świata”. Znaczenie Ukrainy dla Moskwy jest większe, aniżeli powszechnie się przyjmuje nad Wisłą, ponieważ stanowi ona jedno ze świętych centrów prawosławia. Jednakże polska polityka nie musi być przepełniona destruktywnym lękiem lub nierozumnymi uprzedzeniami wobec Kremla, a wzmacniania stosunków polsko-rosyjskich, zwłaszcza na płaszczyźnie społecznej, kulturalnej i ekonomicznej, nie trzeba od razu interpretować jako haniebnej zdrady naszych wartości. Warto podkreślić, iż zaangażowanie Polski w „pomarańczową rewolucję”, a po dekadzie w wydarzenia na Majdanie, polegało niestety w znacznej mierze na składaniu „czczych deklaracji”, które skutkowały niczym innym, jak tylko obciążaniem relacji z Moskwą. Prawdą jest, iż wola dominacji nad Kijowem stanowiła przez stulecia kość niezgody z Rosją. Choć w końcu niepodległość naszego wschodniego sąsiada - zgodnie ze szkołą J. Giedroycia - została zaakceptowana przez Warszawę, to jednak Kreml wciąż postrzega terytorium nad Dnieprem jako 
własną strefę wpływów, co nie powinno nigdy umykać sterownikom polskiej nawy państwowej.

Podejmowanie skutecznej aktywności regionalnej na własną rękę wydaje się zaledwie ułudą, a przecież Polska nie może pozwolić sobie na politykę abstrahującą od szerszego kontekstu geopolitycznego. Mimo obecnych, niebagatelnych „ruchów tektonicznych” w Brukseli, warto podążać tymi ścieżkami, które pozwalają korzystać z unijnego potencjału, po uprzednim przekonaniu partnerów do polskiej wizji, gdyż tylko w ten sposób Rzeczpospolita pozyska międzynarodowe poparcie dla własnych postulatów. To przecież z uwagi na nikłość rodzimego potencjału Warszawa zdecydowała się przystąpić do Unii, by multiplikować swe polityczne znaczenie na arenie międzynarodowej (Grodzki, 2009). Obok istotnych wątpliwości co do skuteczności samotnie podejmowanych działań, realizacja polityki regionalnej poza nawiasem wspólnoty europejskiej mogłaby być powszechnie uznawana za nazbyt „imperialną” w swej wymowie, a każdorazowe odcięcie się od Unii mogłoby - niestety - obniżać rangę polskich działań dyplomatycznych, zwłaszcza wobec obszaru byłego ZSRR. W razie utrzymywania niebezpiecznego dystansu względem Brukseli, coraz bardziej ewidentnego po wyborach 2015 r., Polska - zakleszczona między dwoma przeciwstawnymi blokami - będzie potencjalnie ulegać dalszej peryferyzacji (Niedźwiecki, 2016).

Jednak według twardych zwolenników „polityki jagiellońskiej”, będących obecnie architektami polityki zagranicznej RP (Waszczykowski, 2016), unijne działania na Wschodzie charakteryzują się słabowitością, a coraz wydatniej zdezintegrowana wspólnota europejska zdominowana jest przez największych graczy (tj. Francję, Niemcy i Włochy), posiadających odmienną percepcję wyzwań geopolitycznych aniżeli państwa EŚW. Z uwagi na powyższe ich zdaniem należy budować raczej własny nurt w Unii bądź stać się liderem odrębnej struktury w regionie, jako przeciwwagi dla dominujących podmiotów, czyli $\mathrm{w}$ istocie hołdować antyunijnej filozofii: „brać co nasze, a reszty nie traktować zbyt poważnie”. Biorąc pod uwagę powyższe, jedynym godnym sojusznikiem $\mathrm{w}$ polityce wschodniej ma być Waszyngton, posiadający wolę oraz zdolności do podjęcia aktywności na terytorium byłego ZSRR. Jednakże wielokrotnie przekonywaliśmy się, że pozycja Rzeczpospolitej w EŚW jest bardziej pochodną jej znaczenia we wspólnocie, niż stopnia jej poparcia na Kapitolu, a zatem Warszawa winna raczej przyłożyć się do efektywniejszego „lobbyingu” w Brukseli, zamiast liczyć na mgliste obietnice USA (Kuźniar, 2008). Co więcej, porzucenie przez Polskę jej straceńczej misji na Wschodzie mogłoby poprawić jej stosunki z Moskwą, przyczyniając się równocześnie do poprawy istotnie nadwątlonego wizerunku 
Warszawy w strukturach europejskich. Nie ulega wątpliwości, że wojna na Ukrainie już ostudziła zapędy rodzimych patriotów, zazwyczaj skorych do ryzykownej donkiszoterii na obszarze postsowieckim. Następnym krokiem mogłaby być koordynacja działań dyplomatycznych z państwami „starej Europy”, czego nie trzeba interpretować jako „wywieszania białej flagi”, lecz jako konstruktywną politykę, prowadzącą do osiągnięcia założonych celów. Zdolność do wchodzenia w konflikt polityczny z Unią nie stanowi bowiem żadnej miary skuteczności w polityce europejskiej (Żurawski vel Grajewski, 2010).

\section{PODSUMOWANIE}

W aktualniej sytuacji politycznej prowadzenie efektywnych działań zewnętrznych, nieulegających zgubnym ideologicznym manifestacjom, może uwzględniać użycie wspólnotowego instrumentarium, nawet pomimo ewidentnych perturbacji w Unii, wywołanych tzw. „Brexitem”. Odpowiedzią na polskie dylematy geopolityczne nie są bowiem samotne ,jagiellońskie eskapady”, gdyż - do pewnego stopnia - mogą one stanowić przeciwieństwo istniejących filarów bezpieczeństwa narodowego, tj. wspólnoty atlantyckiej uzupełnionej o - wprawdzie dość efemeryczną, aczkolwiek niezwykle potrzebną - unijną współpracę. Redukowanie polskiej polityki do anachronicznych fantazji o środkowoeuropejskiej federacji mogłoby - niestety - potencjalnie podmywać pozycję państwa w strukturach euroatlantyckich. A przecież to członkostwo w instytucjach świata zachodniego, polegające m.in. na współpracy z Niemcami, stanowiło o powodzeniu Rzeczpospolitej w ostatnich latach, choć aktualnie nie przystaje ono również do historycznej koncepcji „polityki piastowskiej”, głównie z uwagi na obserwowany proces dezintegracji wspólnoty.

W sensie emocjonalnym era aktywnej „polityki mocarstwowej” zakończyła się wraz z katastrofą prezydenckiego samolotu w 2010 r. Jednak mimo wszystko Rzeczpospolita nie musi rezygnować z prób promocji własnych preferencji w regionie, lecz może wzmocnić swą aktywności w tym zakresie, zwłaszcza w ramach działań zewnętrznych UE. Nie do pomyślenia jest przecież, by na forum unijnym Francja lub Hiszpania przykładowo odstąpiły od popierania spraw obszaru Morza Śródziemnego albo by Szwecja abdykowała z roli, jaką odgrywa na Bałtyku. Sporym błędem byłoby zatem wyrzucenie polskiej polityki wschodniej poza zakres unijnej kooperacji, co oznaczałoby przecież zgubną w skutkach rezygnację z używania potencjału całej wspólnoty. W przeszłości 
zacieśnianie integracji z tzw. „Zachodnioeuropejskim mainstreamem” przynosiło bowiem Polsce pozytywne rezultaty, przykładowo w postaci Partnerstwa Wschodniego, stanowiącego współczesne ujęcie tradycyjnych polskich interesów geopolitycznych, a zatem próbę przeniesienia „idei jagiellońskiej” w XXI wiek, co dawało nadzieję na odrzucenie narracji „mocarstwowej”, jak również dostosowanie działań do wymogów ponadnarodowego otoczenia.

Dziś rozsądnym przejawem aktywnej polityki w regionie może być popieranie geograficznego rozszerzenia procesu integracyjnego w jego rozmaitych formułach, nawet mimo coraz bardziej ewidentnego kryzysu wspólnoty, który rozgrywa się na naszych oczach. Tymczasem polskie władze po wyborach 2015 r. niestety skupiają się bardziej na wydawaniu "strzelistych deklaracji” co do przyszłego kształtu politycznego omawianego regionu niż podejmowaniu konkretnych działań. Należy zauważyć, iż w porównaniu do oferty Niemiec, Stanów Zjednoczonych czy nawet Rosji, polskie propozycje wyglądają raczej mizernie, a powszechne w EŚW poczucie „braku sprawczości” Warszawy nie stanowi najlepszego prognostyku na przyszłość. Aktualnie Rzeczpospolita wydaje się nie dysponować środkami do urzeczywistnienia koncepcji „Międzymorza” w jakiejkolwiek konfiguracji, a marnotrawienie szczupłych zasobów może powodować nadszarpnięcie wątłych podstaw polskiej państwowości. Próba prowadzenia rodzaju „polityki mocarstwowej” wywoływała do tej pory jedynie frustrujący dysonans między oczekiwaniami, a faktycznymi możliwościami aktywności Warszawy. Biorąc pod uwagę powyższe, paląca potrzeba realnego wzmacniania podstaw polskiego bezpieczeństwa, zwłaszcza w dobie kwestionowania strategicznych pewników, wymaga bardziej zacieśnienia euroatlantyckiej kooperacji aniżeli samotnych eskapad pod hasłem ,jagiellońskich ambicji”. Jednak wzorcem do działania nie może być również osławiona „polityka piastowska”, gdyż coraz dotkliwszy kryzys, jaki obecnie obserwujemy w Europie, wymaga wykrystalizowania się zupełnie nowego podejścia, bardziej przystającego do współczesnych wyzwań.

\section{Bibliografia:}

Bartosiak, J. (2014). Polska droga od słabości do siły. Nowa Konfederacja, 3(54). Pobrane z: http://www.nowakonfederacja.pl/polska-droga-od-slabosci-do-sily/.

Bączkowski, W. (1938). Uwagi o istocie siły rosyjskiej. Wschód-Orient. Kwartalnik poświęcony sprawom Wschodu. Pobrane z: http://www.omp.org.pl/artykul.php?artykul=115. 
Bocheński, A. (1927). Imperializm nacjonalistyczny a imperializm państwowy. Myśl mocarstwowa, 1. Pobrane z: http://www.omp.org.pl/artykul.php?artykul=346.

Chodubski, A.J. (2006). Wstęp do badań politologicznych. Gdańsk: Wydawnictwo Uniwersytetu Gdańskiego.

Cichocki, M.A. (2010). Rzeczpospolita utracony skarb Europy. W: J. Kloczowski. Władza w polskiej tradycji politycznej. Idee i praktyka. Kraków: Ośrodek Myśli Politycznej. Pobrane z: http://www.omp.org.pl/artykul.php?artykul=52.

Grodzki, R. (2009). Polska polityka zagraniczna w XX i XXI wieku. Główne kierunki Fakt - Ludzie - Wydarzenia. Zakrzewo: Wydawnictwo Replika.

Kędzierski, M. (2014). Czas na Międzymorze. Nowa Konfederacja, 3(54). Pobrane z: http://www.nowakonfederacja.pl/czas-na-miedzymorze/.

Konopacki, S. (2010). Z Maison-Laffitte patrzono szerzej. Nowa Europa Wschodnia, 5. Pobrane z: http://www.new.org.pl/9,post.html.

Kowal, P. (2009). Cienie Piastów. Nowa Europa Wschodnia, 6. Pobrane z: http://www. new.org.pl/29,numer.html.

Kuź, M. (2014). Zamilknąć nie znaczy zapomnieć. Nowa Konfederacja, 3(54). Pobrane z: http://www.nowakonfederacja.pl/zamilknac-nie-znaczy-zapomniec/.

Kuźniar, R. (2008). Droga do wolności. Polityka zagraniczna III Rzeczypospolitej. Warszawa: Wydawnictwo naukowe SCHOLAR.

Lazari de, A. (2006). Jerzego Giedroycia wołanie na puszczy. Przegląd, 30. Pobrane z: http://www.tygodnikprzeglad.pl/jerzego-giedroycia-wolanie-na-puszczy/.

Najder, Z. (2010). Doktryna ULB - koncepcja Giedroycia i Mieroszewskiego w XXI wieku. Komentarz Międzynarodowy Pułaskiego. Maj. Pobrane z: http://www. new.org.pl/99,post.html.

Niedźwiecki, A. (2016). Jak wydostać się z peryferii? Polska polityka europejska po 1989 r. W: M. Pietrasiak, M. Stelmach, K. Żakowski (red.). Polityka zagraniczna Polski. 25 lat doświadczeń. Łódź: Wydawnictwo Uniwersytetu Łódzkiego. Pobrane z: http://dspace.uni.lodz.pl:8080/xmlui/handle/11089/19003?show=full.

Nowak, A. (2004). Od Imperium do Imperium. Spojrzenie na historie Europy Wschodniej. Kraków: Wydawnictwo ARCANA.

Nowak, A. (2010). Polska polityka wschodnia: historyczne inspiracje i współczesne dylematy. W: J. Kloczkowski, T. Żukowski (red.), Rzeczpospolita na arenie międzynarodowej. Idee i praktyczne dylematy polityki zagranicznej. Kraków-Warszawa: Ośrodek Myśli Politycznej. Pobrane z: http://www.omp.org.pl/artykul.php?artykul=18.

Rojek, P. (2012). Teoria Strefy Środkowej. Kazimierz Smogorzewski i aktualność polskiego federalizmu. Pressje. Teka 30-31. Pobrane z: http://pressje.pl/media/ pressje_shop/article/article__issue_298.pdf.

Sikorski, R. (2011). Polska a przyszłość Unii Europejskiej. Pobrane z: http://msz.gov.pl/ resource/c2a33d88-7b8d-4fa5-8680-a67a4b2b38af:JCR.

Szatkowski, T. (2015). Nie ma przywództwa bez siły. Nowa Konfederacja, 1(55). Pobrane z: http://www.nowakonfederacja.pl/nie-ma-przywodztwa-bez-sily/.

Szczerski, K. (2008). Dynamika systemu europejskiego. Rozważania o nowym kształcie polityki w Unii Europejskiej. Kraków: Wydawnictwo Uniwersytetu Jagiellońskiego. 
Ujazdowski, K.M. (2008). Polska państwem rewizjonistycznym. Koncepcje geopolityczne Adolfa Bocheńskiego. W: J. Kloczowski. Przeklęte miejsce Europy? Dylematy polskiej geopolityki. Kraków: Ośrodek Myśli Politycznej.

Waszczykowski, W. Informacja Ministra Spraw Zagranicznych o zadaniach polskiej polityki zagranicznej w 2016 r. Pobrane z: http://www.mfa.gov.pl/pl/aktualnosci/ wiadomosci/minister_witold_waszczykowski_o_priorytetach_polskiej_dyplomacji. Żurawski vel Grajewski, P. (2010). Polityka polska na forum Unii Europejskiej 2005-2007 a cele polityczne Rzeczypospolitej - próba oceny. W: J. Kloczkowski, T. Żukowski (red.), Rzeczpospolita na arenie międzynarodowej. Idee i praktyczne dylematy polityki zagranicznej. Kraków-Warszawa: Ośrodek Myśli Politycznej. Pobrane z: http://www.omp.org.pl/stareomp/index5dd4.html?module=subjects\&func=viewpage\&pageid $=771$. 